\title{
Flavonoids Isolated from Vitex grandifolia, an Underutilized Vegetable, Exert Monoamine A \& B Inhibitory and Anti-inflammatory Effects and Their Structure-activity Relationship
}

\author{
Az Kullanılan Bir Bitki, Vitex grandifolia'dan İzole Edilen Flavonoidlerin \\ Monoamin A \& B İnhibitör ve Anti-enflamatuvar Etkileri ve Yapı-aktivite \\ İlişkisi
}

\author{
(1) Oluwasesan M. BELLO1,2*, (1) Abiodun B. OGBESEJANA1 ${ }^{1}$, (1) Charles Oluwaseun ADETUNJI33 (1) Stephen 0. OGUNTOYE2 \\ ${ }^{1}$ Federal University Dutsin-Ma, Department of Applied Chemistry, Katsina State, Nigeria \\ 2University of Ilorin, Department of Chemistry, Kwara State, Nigeria \\ 3Edo University lyamho, Department of Microbiology, Applied Microbiology, Biotechnology and Nanotechnology Laboratory, KM 7, Auchi-Abuja Road, \\ lyamho, Edo State, Nigeria
}

\begin{abstract}
Objectives: Vitex grandifolia belongs to family Lamiaceae; it consists of flowering plants and it is also called the mint family. The Yoruba people of southwest Nigeria called it "Oriri" or "Efo oriri". This plant is classified as an underutilized vegetable and little is known about its phytochemistry or its biological evaluations.

Materials and Methods: Methanol extracts of the dried leaves and stem of the plant were subjected to fractionation and isolation using vacuum layer and column chromatography methods. The structures of the compounds were elucidated using spectroscopic techniques including IR, 1D-, and 2D-NMR and by comparison with the data reported in the literature. They were evaluated in vitro for the inhibition of monoamine recombinant human MAO-A and -B and anti-inflammatory activities.

Results: Three known flavonoids were isolated from the methanolic extract of the leaves of $V$. grandifolia for the first time to the best of our knowledge, i.e. isoorientin (1), orientin (2), and isovitexin (3). Most of the isolated compounds showed selective inhibition of monoamine oxidase B, inhibition of MAO-B by isoorientin (1) and orientin (2) were 9 -fold more potent (IC $(\mu \mathrm{g} / \mathrm{mL})$ of 11.08 and 11.04$)$ compared to the inhibition of $\mathrm{MAO}$ - $\mathrm{A}$ $\left(\mathrm{IC}_{50}(\mu \mathrm{g} / \mathrm{mL})\right.$ of $\left.>100\right)$, while clorgyline and deprenyl were used as positive standards. The isolated flavonoids displayed good activity against the $\mathrm{NF}-x \mathrm{~b}$ assay with $\mathrm{IC}_{50}(\mu \mathrm{g} / \mathrm{mL})$ of $8.9,12$, and 18 . This study establishes a link between the structure and the biological activities on the basis of the different patterns of substitution, particularly the $\mathrm{C} 2=\mathrm{C} 3$ double bond and the position of glucose moiety.

Conclusion: This study is the first to establish the phytochemistry of the polar part of $V$. grandifolia and the anti-inflammatory and neuroprotective role of these isolated compounds.
\end{abstract}

Key words: Vitex grandifolia, underutilized vegetable, lupeol, MAO-A and B, neurodegenerative

öz

Amaç: Vitex grandifolia, Lamiaceae familyasına aittir; çiçekli bitkilerden oluşur ve aynı zamanda nane ailesi olarak da bilinir. Güneybatı Nijerya'daki Yoruba halkı bitkiyi "Oriri” veya "Efo oriri” olarak adlandırmaktadır. Bu bitki az kullanılan bir bitki olarak sınıflandırılır ve fitokimyası veya biyolojik etkileri hakkında çok az bilgi bulunmaktadır.

Gereç ve Yöntemler: Kurutulmuş yaprak ve gövdelerden hazırlanan metanol ekstreleri üzerinde, vakum ve açık kolon kromatografısi metotları kullanılarak fraksiyonlama ve izolasyon çalışmaları yapılmıştır. Bileşiklerin yapıları, IR, 1D- ve 2D-NMR teknikleri kullanılarak ve literatürdeki verilerle

*Correspondence: E-mail: obello@fudutsinma.edu.ng, Phone: +2348062320327 ORCID: orcid.org/0000-0003-1431-7319

Received: 20.06.2018, Accepted: 16.08.2018

-Turk J Pharm Sci, Published by Galenos Publishing House. 
karşılaştırılarak aydınlatılmıştır. Bileşikler, monoamin rekombinant insan MAO-A ve -B inhibisyonu ve anti-enflamatuvar aktiviteleri yönünden in vitro olarak değerlendirilmiștir.

Bulgular: V. grandifolia'nın yapraklarının metanollü ekstresinden bilinen üç flavonoid bileșiği izoorientin (1), orientin (2) ve isoviteksin (3) ilk kez izole edilmiştir. İzole edilen bileşiklerin çoğu, monoamin oksidaz B'ye karşı seçici inhibisyon etki göstermiştir, MAO-B'nin izoorentin (1) ve orientin (2) tarafından inhibisyonu ( $\left(\mathrm{C}_{50}(\mu \mathrm{g} / \mathrm{mL}), 11.08\right.$ ve 11.04), MAO-A'nın inhibisyonuna $\left(\mathrm{IC}_{50}(\mu \mathrm{g} / \mathrm{mL})>100\right)$ kıyasla 9 kat daha etkili bulunmuştur. Kloril ve deprenil pozitif standartlar olarak kullanılmıștır. İzole edilen flavonoitler NF-xb testine karşı 8.9, 12 ve $18 \mathrm{IC}$ ( $(\mu \mathrm{g} / \mathrm{mL})$ değerleri ile yüksek aktivite göstermiştir. Bu çalıșma, yapıdaki değişik sübstitüsyonlara, özellikle C2=C3 arasındaki çifte bağ ve glukozun konumuna bağlı olarak yapı ile biyolojik aktivite arasında bir bağlantının olduğunu ortaya koymuştur.

Sonuç: Bu çalışma V. grandifolia'nın polar fraksiyonunun fitokimyasal profilini ortaya koyan ve izole edilen bileşiklerin anti-enflamatuvar etkisini ve nöroprotektif rolünü gösteren ilk çalışmadır.

Anahtar kelimeler: Vitex grandifolia, az kullanılan bitki, lupeol, MAO-A ve B, nörodejeneratif

\section{INTRODUCTION}

Pathological and neurodegenerative paths, cancer, and Alzheimer, coronary and Parkinson diseases are the result of free radical-mediated reactions and reactive oxygen species from the human body.,2 In the many epidemiological studies carried out, it was discovered that there is a strong connection between people whose diets are rich in fresh fruits and leafy vegetables and low incidence of cardiovascular diseases, neurodegenerative diseases, and some particular forms of cancer. ${ }^{3}$ Many studies and investigations have been dedicated to the antioxidant effects of compounds in fruits, medicinal plants, and vegetables so as to improve human health and regulate physiological functions. Monoamine oxidases (MAO-A and $\mathrm{MAO}-\mathrm{B}$ ) are mitochondrial enzymes that oxidatively deaminate monoaminergic neurotransmitters and (potentially harmful) dietary monoamines. Their major purpose is the regulation of noradrenaline, dopamine, serotonin, and adrenaline in the brain. ${ }^{4}$ The study of MAO-A and -B has been of significant pharmacological attention recently and their inhibitors (MAOIs) have found extensive medical use for the management of numerous neurological and psychiatric maladies. These enzymes remove as well as catalyze exogenous amines. The MAO-A inhibitors are important in managing anxiety and depression while the MAO-B inhibitors are effective in inhibiting and treating Alzheimer and Parkinson diseases. ${ }^{5-7}$

Medicinal plants, i.e. vegetables, botanical extracts, and herbal products from natural sources, have been viewed as an important and primary basis for MAOs' inhibitors and this validates the cultural application of many botanicals as substitutes for the management of depression, Parkinson disease, and other neuropsychiatric as well as neurological disorders. ${ }^{8}$ Flavonoids as secondary metabolites are one of the most popular polyphenols present in medicinal plants, they are broadly distributed in many plant species, and they can be found in various parts of these plants, i.e. bark, flowers, fruits, leaves and stems. ${ }^{9-12}$ Flavonoids have been reported to display a large variety of biological activities; some of these are antioxidants and enzyme inhibitors, while others have anti-inflammatory, anticancer, antihyperglycemic, and hepatoprotective activities. ${ }^{13-16}$

In recent times, research on medicinal plants has globally increased tremendously, and volumes of reputable evidence have been gathered to portray the enormous prospects of medicinal plants used in traditional systems. ${ }^{17,18}$ Many of these herbal plants have been identified and studied using current scientific methods, and the results revealed the immense promise of medicinal plants in the field of medical science. ${ }^{19}$ Vitex grandifolia, which belongs to the family Lamiaceae, bears fruit that is edible and used to make an alcoholic drink by the locals, while the bark is used to treat stomachache, diarrhea, bronchial complaints, rickets, sores, and fever. It is also used in the treatment of colic, infections of the umbilical cord, toothache, rheumatism, and orchitis. Epidi and Odili20 (2009) reported the biocidal effect of the powdered leaf of $V$. grandifolia against Tribolium castaneum in stored groundnut Arachis hypogaea. The plant is a shrub or small tree about 10-12 cm in length and 5-7 $\mathrm{cm}$ in width, trunk to $60 \mathrm{~cm}$ girth, bearing a spreading crown, in high deciduous forest or secondary jungle. Local names of this plant species are Oori ọdan (Yoruba, Nigeria), ofonma (Egun, Republic of Benin), and ofofrin (Setangun, Republic of Benin). ${ }^{21}$ Surprisingly, this plant's phytochemistry has not being looked into although it is a vegetable. Thus, its study and that of the isolated compounds, i.e. biological activities from this plant, will be considered worthwhile. Hence, the present study reports the isolation, characterization, and in vitro inhibition of MAO-A and -B of the constituents from polar extract of $V$. grandifolia.

\section{MATERIALS AND METHODS}

\section{Collection of plant samples}

The leaves with the stem of $V$. grandifolia was collected in AprilOctober 2015 from Ilorin metropolis, Kwara State, Nigeria. The collected plant was identified by a taxonomic botanist in the department of Plant Biology, University of Ilorin, Ilorin, where a voucher number was obtained after the deposit of the specimen. The leaves and stem were air dried, powdered, and stored for further analysis.

\section{Extraction of the plant materials}

The air-dried and powdered plant material was defatted with hexane and then was prepared by maceration $(1.5 \mathrm{~kg}$ ) with $7 \mathrm{~L}$ of methanol $(\mathrm{MeOH})$ at ambient temperature for $24 \mathrm{~h}$. The process was repeated three times, and the filtrates were combined and evaporated under vacuum to dryness.

\section{General experimental procedure}

Precoated TLC plates (AluO); Silica gel $60 \mathrm{~F}_{254}$; layer thickness $0.25 \mathrm{~mm}$ (Merck). Precoated TLC plates (Glass); RP-18 $\mathrm{F}_{254^{\prime}}$; 
layer thickness $0.25 \mathrm{~mm}$ (Merck); Silica gel 60; 40-63 $\mu \mathrm{m}$ mesh size (Merck); RP-18; 40-63 $\mu$ m mesh size; Sephadex LH 20; 25-100 $\mu \mathrm{m}$ mesh size (Merck). Silica gel 60 and RP C-18, Diaion HP-20 was used for column chromatography. ${ }^{1} \mathrm{H}$ NMR, ${ }^{13} \mathrm{C}$ NMR, and 2D NMR were recorded on 400, 500, and 600 $(\mathrm{MHz})$ instruments (Agilent and Bruker Inc., California, USA). Chemical shifts were expressed in parts per million ( $\delta$ ) using TMS as internal standard. Values of coupling constant $J$ are reported in $\mathrm{Hz}$. Infrared spectroscopy was performed using a PerkinElmer FT-IR Spectrum Two spectrometer and the masses of the compounds were determined using an Agilent 1260 liquid chromatography system (Agilent, USA) equipped with a quaternary solvent delivery system, and a Triple quad 6410 MS system and Agilent Technologies 6540 UHD Accurate Mass Q-TOF liquid chromatography-mass spectrometer (Agilent, USA).

\section{Fractionation and isolation}

The extract of $V$. grandifolia was defatted using hexane and then extracted with $\mathrm{MeOH}$. $\mathrm{MeOH}$ extract of $V$. grandifolia was added to reverse phase silica gel (RP-18) using vacuum layer chromatography (VLC) for fractionation. Water with increasing $\mathrm{MeOH}$ was used as eluting solvent and the eluates were collected and concentrated on a Rotavapor. TLC was used to check and monitor the isolates and combine the eluates. Eleven fractions were obtained; the first fraction $\left(\mathrm{H}_{2} \mathrm{O}\right.$ only) was picked for further fractionation because the TLC revealed promising compounds. This fraction was subjected to a Diaion HP-20 column for isolation. The column was eluted with water first and then with increasing $\mathrm{MeOH}$ and the eluates were collected and concentrated. Twelve fractions were obtained. All fractions were collected, concentrated, and monitored by TLC. The eighth fraction was loaded onto the column in $\mathrm{CH}_{3} \mathrm{Cl}$ using 65:35:10 $\left(\mathrm{CH}_{3} \mathrm{Cl}: \mathrm{MeOH}: \mathrm{H}_{2} \mathrm{O}\right)$ as eluting solvent. Six fractions were obtained; the third fraction gave compound 3 , which was purified using $\mathrm{CC}$ in $\mathrm{CH}_{3} \mathrm{Cl}$ with 65:35:10 $\left(\mathrm{CH}_{3} \mathrm{Cl}\right.$ : $\left.\mathrm{MeOH}: \mathrm{H}_{2} \mathrm{O}\right)$ as eluting solvent. Fractions 1 and 2 were combined using TLC and two compounds (1 and 2) were isolated from the first fraction after further purification with $\mathrm{CC}$ in $\mathrm{CH}_{3} \mathrm{Cl}$ with 8:2:0.5 $\left(\mathrm{CH}_{3} \mathrm{Cl}\right.$ : $\mathrm{MeOH}: \mathrm{H}_{2} \mathrm{O}$ ) as eluting solvent. Compounds 1 (19 mg), 2 (14.7 $\mathrm{mg}$ ) and $\mathbf{3}$ (10.5 $\mathrm{mg}$ ) (Figure 1) were isolated in pure form after purification.

\section{Monoamine oxidase inhibition assays (MAO)}

To evaluate the outcome of the isolated compounds from $V$. grandifolia on MAO-A and MAO-B, the kynuramine deamination assay was used for 96 -well plates as expressed previously. ${ }^{22}$ The method used was adapted from the reported literature. ${ }^{23,24}$ The isolated constituents did not display any interference with fluorescence measurement, but clorgyline and deprenyl were used as positive controls for the experiment.

\section{Anti-inflammatory activity}

Inhibition of iNOS activity

The assay was performed using mouse macrophages 915 (RAW 264.7, obtained from ATCC). Cells were cultured in phenol 916 red free RPMI medium supplemented with $10 \%$ bovine calf serum, $100 \mathrm{U} / \mathrm{mL}$ penicillin $\mathrm{G}$ sodium, and $100 \mu \mathrm{g} / \mathrm{mL}$ streptomycin at $37^{\circ} \mathrm{C}$ in an atmosphere of $5 \% \mathrm{CO}_{2}$ and $95 \%$ humidity. Cells were seeded in 96-well plates at $5 \times 10^{4}$ cells/well and incubated for 24 h. Test compounds diluted in serum-free medium were added to the cells. After $30 \mathrm{~min}$ of incubation, LPS $(5 \mu \mathrm{g} / \mathrm{mL})$ was added and the cells were further incubated for $24 \mathrm{~h}$. The concentration of nitric oxide (NO) was determined by measuring the level of nitrite released in the cell culture supernatant using Griess reagent. ${ }^{25}$ Percent inhibition of nitrite production by the test compound was calculated in comparison to the vehicle control. $I_{50}$ values were obtained from dose curves. Parthenolide was used as a positive control. ${ }^{26,27}$

\section{Inhibition of $N F-x B$ activity}

The assay was performed in human chondrosarcoma (SW1353, obtained from ATCC) cells as described earlier. Cells were cultured in 1:1 mixture of DMEM/F12 supplemented with $10 \%$ FBS, $100 \mathrm{U} / \mathrm{mL}$ penicillin G sodium, and $100 \mu \mathrm{g} / \mathrm{mL}$ streptomycin at $37^{\circ} \mathrm{C}$ in an atmosphere of $5 \% \mathrm{CO}_{2}$ and $95 \%$ humidity. Cells $\left(1.2 \times 10^{7}\right)$ were washed once in an antibiotic and FBS-free $\mathrm{DMEM} / \mathrm{F} 12$, and then reintroduced in $500 \mu \mathrm{L}$ of antibiotic-free DMEM/F12 containing $2.5 \%$ FBS. NF- $x$ B luciferase plasmid construct was added to the cell suspension at a concentration of $50 \mu \mathrm{g} / \mathrm{mL}$ and incubated for $5 \mathrm{~min}$ at room temperature. The cells were electroporated at $160 \mathrm{~V}$ and one $70-\mathrm{ms}$ pulse using BTX disposable cuvettes, model 640 (4-mm gap), in a BTX Electro Square Porator T 820 (BTX I, San Diego, CA, USA). After electroporation, cells were plated onto the wells of 96 -well plates at a density of $1.25 \times 10^{5}$ cells per well. After $24 \mathrm{~h}$, cells were treated with different concentrations of test compound for 30 min prior to the addition of PMA (70 ng/mL) and incubated for $8 \mathrm{~h}$. Luciferase activity was measured using the Luciferase Assay kit (Promega). Light output was detected on a Spectra-Max plate reader. Percent inhibition of luciferase activity was calculated as compared to vehicle control and $I C_{50}$ values were obtained from dose curves. Sp-1 was used as a control transcription factor that is unresponsive to inflammatory mediators (such as PMA). This is useful in detecting agents that nonspecifically inhibit luciferase expression due to cytotoxicity or inhibition of luciferase enzyme activity. ${ }^{27}$

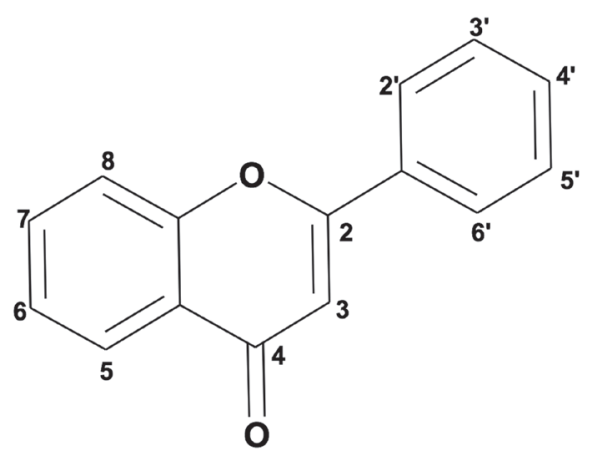

Figure 1. Basic skeleton or structure of flavonoids 


\section{RESULTS}

\section{$M A O-A$ and $-B$}

Most of the isolated compounds showed selective inhibition of either MAO-A or MAO-B as shown in Table 1. The inhibition of MAO-B by both isoorientin (1) and orientin (2), two of the flavonoids isolated from $\mathrm{V}$. grandifolia, was 9-fold more potent $\left(\mathrm{IC}_{50}(\mu \mathrm{g} / \mathrm{mL})\right.$ of 11.08 and 11.04$)$ compared to the inhibition of MAO-A (IC ${ }_{50}(\mu \mathrm{g} / \mathrm{mL})$ of $\left.>100\right)$. Isovitexin (3), a flavonoid isolated from this wild vegetable for the first time displayed fair selective activity against MAO-A $\left(\mathrm{IC}_{50}(\mu \mathrm{g} / \mathrm{mL})\right.$ of $\left.>100\right)$ to MAO-B $\left(\mathrm{IC}_{50}(\mu \mathrm{g} / \mathrm{mL})\right.$ of 21.3$)$ like the other two flavonoids, while clorgyline and deprenyl were used as positive standards.

\section{Anti-inflammation}

The isolated flavonoids, i.e. isoorientin (1), orientin (2), and isovitexin (3), from $V$. grandifolia displayed good activity against the $N F-\kappa b$ assay $\left(I C_{50}(\mu g / m L)\right.$ of $8.9,12$, and 18), although orientin (2) showed moderate activity against the Sp-1 assay with $I_{50}$ of $23 \mu \mathrm{g} / \mathrm{mL}$, while the others displayed poor activity when compared with the positive standard with $\mathrm{IC}_{50}$ of $8 \mu \mathrm{g} / \mathrm{mL}$ as shown in Table 2. Isovitexin (3) exhibited moderate activity against the iNOS assay, while the others, i.e. isoorientin (1) and orientin (2), displayed poor activity with $\mathrm{IC}_{50}$ of 48 and $54 \mu \mathrm{g} /$ $\mathrm{mL}$. The positive standard used in this study was parthenolide.

\section{Isolated compounds}

\section{Compound 1}

Compound 1 (Figure 1) was isolated as a yellow solid. Its molecular formula was deduced to be $\mathrm{C}_{21} \mathrm{H}_{20} \mathrm{O}_{11}$ from a combination of ${ }^{1} \mathrm{H}$ NMR and ${ }^{13} \mathrm{C}$ NMR data. ${ }^{1} \mathrm{H}$ NMR $(600 \mathrm{MHz}$, DMSO-d6) d: $13.2(1 \mathrm{H}$, brs, 5-OH), $7.55(1 \mathrm{H}, d d, J=2.5,9.0 \mathrm{~Hz}$, $60-\mathrm{H}), 7.45(1 \mathrm{H}, d, J=2.5 \mathrm{~Hz}, 20-\mathrm{H}), 6.85(1 \mathrm{H}, d, J=9.0 \mathrm{~Hz}, 50-\mathrm{H})$,

\section{Table 1. IC ${ }_{50}$ values of isolated compounds as MAO-A and -B} inhibitory agents

\begin{tabular}{llll} 
& Sample name & MAO-A $\left(\mathrm{IC}_{50}\right)$ & MAO-B $\left(\mathrm{IC}_{50}\right)$ \\
\hline 1 & Isoorientin (1) & $>100$ & 11.08 \\
\hline 2 & Orientin (2) & $>100$ & 11.04 \\
\hline 3 & Isovitexin (3) & $>100$ & 21.3 \\
\hline 4 & Clorgyline & 1.6 & $\mathrm{NT}$ \\
\hline 5 & Deprenyl & NT & 0.48 \\
\hline
\end{tabular}

Table 2. IC ${ }_{50}$ values of isolated compounds as anti-inflammatory agents

\begin{tabular}{llllll} 
& Test compounds & NF-KB & SP-1 & iNOS & $\begin{array}{l}\text { \% Cell death at the } \\
\text { highest conc }(100 \\
\mu \mathrm{g} / \mathrm{mL})\end{array}$ \\
\hline 1 & Isoorientin (1) & 8.9 & 63 & 48 & 63.89 \\
\hline 2 & Orientin (2) & 12 & 23 & 54 & \\
\hline 3 & Isovitexin (3) & 18 & 41 & 21 & \\
\hline 4 & Parthenolide & 0.9 & 6.5 & 0.18 & \\
\hline 5 & Parthenolide & 0.6 & 8 & 0.15 & \\
\hline
\end{tabular}

$6.63(1 \mathrm{H}, \mathrm{s}, 3-\mathrm{H}), 4.7(1 \mathrm{H}, d, J=9.7 \mathrm{~Hz}, 100-\mathrm{H}) .{ }^{13} \mathrm{C}$ NMR $(150 \mathrm{MHz}$, DMSO-d6) d: 163.24 (C-2), 102.68 (C-3), 182.32 (C-4), 160.74 (C5), 108.88 (C-6), 164.41 (C-7), 98.53 (C-8), 156.36 (C-9), 102.68 (C-10), $122.24\left(C-1^{\prime}\right), 114.34$ (C-2'), 146.22 (C-3'), 150.16 (C-4'), 116.00 (C-5'), 119.71 (C-6'), 73.76 (C-1"), 70.13 (C-2'), 79.12 (C3"), 70.06 (C-4"), 82.35 (C-5"), 62.01 (C-6"). Compound 1 was identified as isoorientin, by NMR analysis and comparison with its literature data. ${ }^{28}$

\section{Compound 2}

Compound 2 (Figure 1) was obtained as a yellow solid. Its molecular formula was deduced to be $\mathrm{C}_{21} \mathrm{H}_{20} \mathrm{O}_{11}$ from a combination of ${ }^{1} \mathrm{H}$ NMR and ${ }^{13} \mathrm{C}$ NMR data. ${ }^{1} \mathrm{H}$ NMR $(400 \mathrm{MHz}$, DMSO-d6) d: 3.22-3.88 (6H, m, glucosyl-H), $4.69(1 \mathrm{H}, d, J=9.9$ $\left.\mathrm{Hz}, \mathrm{H}-1^{\prime \prime}\right), 6.25(1 \mathrm{H}, \mathrm{s}, \mathrm{H}-6), 6.64(1 \mathrm{H}, \mathrm{s}, \mathrm{H}-3), 6.86(1 \mathrm{H}, d, J$ $\left.=8.4 \mathrm{~Hz}, \mathrm{H}-5^{\prime}\right), 6.86(1 \mathrm{H}, d d, J=2,8.4), 7.48(1 \mathrm{H}, d, J=2.0 \mathrm{~Hz}$, $\left.\mathrm{H}-2{ }^{\prime}\right), 7.54\left(1 \mathrm{H}, d d, J=2.0,8.4 \mathrm{~Hz}, \mathrm{H}-6\right.$ ') $13.20(1 \mathrm{H}, \mathrm{s}, 5-\mathrm{OH}) .{ }^{13} \mathrm{C}$ NMR (100 MHz, DMSO-d6) d: 164.4 (C-2), 102.7 (C-3), 182.3 (C4), 160.74 (C-5), 98.53 (C-6), 163.24 (C-7), 104.91 (C-8), 156.86 (C-9), 104.28 (C-10), 122.24 (C-1'), $114.34\left(C-2^{\prime}\right), 146.22\left(C-3^{\prime}\right)$, 150.16 (C-4'), 116.00 (C-5'), $119.71\left(\mathrm{C}-6^{\prime}\right), 73.76$ (C-1'), 71.13 (C-2"), 79.12 (C-3"), 71.06 (C-4"), 82.35 (C-5"), 62.04 (C-6"). Compound 2 was identified as orientin by NMR analysis and comparison with its literature data. ${ }^{29}$

\section{Compound 3}

Compound 3 (Figure 1) (19 mg) was isolated as a yellow amorphous powder and the melting point is $219-221^{\circ} \mathrm{C}$; IR $\mathrm{v}$ $\max \left(\mathrm{cm}^{-1}\right): 3320(-\mathrm{OH}), 1697(\mathrm{C}=0), 1645(\mathrm{C}=0)$; the molecular formula was deduced to be $\mathrm{C}_{21} \mathrm{H}_{19} \mathrm{O}_{10}$ from a combination of ${ }^{1} \mathrm{H}$ NMR and ${ }^{13} \mathrm{C}$ NMR data. ${ }^{1} \mathrm{H}$ NMR (DMSO-d6): $\delta_{H}: 13.55(1 \mathrm{H}$, brs, 5-OH), $7.93\left(2 \mathrm{H}, d, J=8.8 \mathrm{~Hz}, 3^{\prime}, 5^{\prime}-\mathrm{H}\right), 6.93(2 \mathrm{H}, d, J=8.4 \mathrm{~Hz}$, $\left.2^{\prime}, 6^{\prime}-\mathrm{H}\right), 6.78(1 \mathrm{H}, \mathrm{s}, 3-\mathrm{H}), 6.51(1 \mathrm{H}, \mathrm{s}, 8-\mathrm{H}), 4.55(1 \mathrm{H}, d, J=9.8$ $\left.\mathrm{Hz}, 1{ }^{\prime \prime}-\mathrm{H}\right), 3.11-4.03\left(6 \mathrm{H}, \mathrm{m}\right.$, glucosyl-H). ${ }^{13} \mathrm{C} \mathrm{NMR}(500 \mathrm{MHz}$, DMSO-d6) $\delta_{C}: 164.36$ (C-2), 104.25 (C-3), 182.81 (C-4), 161.52 (C-5), 109.75 (C-6), 164.17 (C7), 94.48 (C-8), 157.08 (C-9), 103.65 (C-10), $121.96\left(C-1^{\prime}\right), 129.34\left(C-2^{\prime}, 6^{\prime}\right), 116.84\left(C-3^{\prime}, 5^{\prime}\right), 162.04$ (C-4'), $73.91\left(\mathrm{C}^{\prime \prime}\right), 71.47$ (C-2"), 79.80 (C-3"), 71.06 (C-4"), 82.46 (C-5"), 62.34 (C-6"). Compound 3 was identified as isovitexin by NMR analysis and comparison with its literature data. ${ }^{30-32}$

\section{Structure-activity relationship}

\section{Anti-inflammatory activity}

The following preliminary structure-activity relationship (SAR) profile is proposed based on the anti-inflammatory effects of the flavonoids that were isolated from $V$. grandifolia; these are summarized as the following: (a) the $\mathrm{C}_{2}=\mathrm{C}_{3}$ double bond might contribute to the activity of these flavonoids as antiinflammatory agents; Wang et al. ${ }^{33}$ reported that the $\mathrm{C}_{2}=\mathrm{C}_{3}$ double bond might contribute to molecular planarity, and this was discovered from the more significant anti-inflammatory effect displayed by diosmetin than hesperetin, and its nonexistence $\left(\mathrm{C}_{2}=\mathrm{C}_{3}\right.$ double bond) resulted in a greater volume/ratio; ${ }^{34}$ (b) Hydroxylation substitution $(-\mathrm{OH})$ noted at both $\mathrm{C}-3^{\prime}$ and 4', i.e. tertiary increases activity especially at ring $B$ moiety, i.e. isoorientin (1), orientin (2); Wang et al. ${ }^{33}$ reported the hydroxylation pattern, its importance in C- $3^{\prime}$-hydroxylation in 
the case of fisetin and 5-hydroxylation in the case of isoflavones gives significant effects for inducing cell delineation (apigenin vs. chrysin) especially ring $B$ moiety; ${ }^{34}$ (c) the position of the sugar moiety and glycosides on ring $A$ gives better antiinflammatory activity than on rings $B$ and $C$; Isoda et al. gave an assessment that glycosides with significant hydrophilicity displayed lower anti-inflammatory activity, which may be due to lower hydrophobicity as well as steric interference, lessening membrane permeability. ${ }^{35}$

\section{$M A O-A$ and $-B$}

The following preliminary SAR profile is proposed based on the inhibitory effects of the flavonoids against MAO-A and -B isolated from $V$. grandifolia; these are summarized as follows: (a) Hydroxylation substitution pattern $(-\mathrm{OH})$ noted at both $\mathrm{C}-3^{\prime}$ and 4', i.e. tertiary increases inhibitory activity of MAO-A and -B mostly at ring B moiety, i.e. isoorientin (1) and orientin (2) (Figure 2) but reduced activity was noted in isovitexin (3) (Figure 2), although Spencer et al. attested to the fact that both unsaturation degree of the $\mathrm{C}_{2}=\mathrm{C}_{3}$ double bond and the hydroxylation pattern on ring $B$ moiety have great significant on the anti-neurodegenerative effects on flavonoids in general. ${ }^{36}$

\section{DISCUSSION}

Compounds 1-3 (Figure 2) were known based on their 1D and 2D NMR and by comparison of their NMR data with those reported in the literature. ${ }^{28,29}$ Isoorientin (1), orientin (2), and isovitexin (3) were isolated from $V$. grandifolia for the first time to the best of our knowledge. The observation in the UV spectrum was an indication of the presence of hydroxyl groups at C-4', C-5, and C-7. Compound 1 showed hydroxyl $\left(3376 \mathrm{~cm}^{-1}\right)$, carbonyl $\left(1660 \mathrm{~cm}^{-1}\right)$, and aromatic groups $\mathrm{C}=\mathrm{C}, \mathrm{CH}_{2}$, and $\mathrm{C}-\mathrm{H}$ bending at 1561, 1446, 845, and $800 \mathrm{~cm}^{-1}$ absorptions in its IR spectrum. The ${ }^{1} \mathrm{H}$ NMR spectrum of compound 1 indicated that $B$ ring protons $\mathrm{H}-2^{\prime}$ and $\mathrm{H}-6^{\prime}$ gave a multiplet at $\delta 7.80$ and an $\mathrm{H}-5^{\prime}$ proton signal was observed at $6.8 \mathrm{ppm}$ as a doublet ( $\mathrm{J}=9$ $\mathrm{Hz}) \mathrm{H}-8$ and $\mathrm{H}-3$ protons were at $\delta 6.75(1 \mathrm{H}, \mathrm{s})$ and $\delta 6.25$ $(1 \mathrm{H}, \mathrm{s})$, respectively. An anomeric proton was observed at $\delta$ $4.93\left(1 \mathrm{H}, d, J=7 \mathrm{~Hz}, \mathrm{C}\right.$-glucosyl $\left.\mathrm{H}-1^{\prime \prime}\right)$ and sugar proton signals overlapped at $\delta$ 3.5-4.8. The spectroscopic results correlated well to the reported data; hence compound 1 is isoorientin. The complete ${ }^{1} \mathrm{H}$ and ${ }^{13} \mathrm{C}$ NMR assignments of compound 2 were conducted by a combination of ${ }^{1} \mathrm{H},{ }^{13} \mathrm{C},{ }^{13} \mathrm{C}$ DEPT, COSY, HSQC, and $\mathrm{HMBC}$ experiments and by comparing with assignments published in the literature as orientin. The presence of a $-\mathrm{OH}$ group at $\mathrm{C}-5^{\prime}$ and $\mathrm{C}-4^{\prime}$ in flavonoid was confirmed. In the ${ }^{13} \mathrm{C}$ NMR spectrum, 2 displayed one anomeric carbon signal at $\delta$ 104.8 and other sugar moiety signals due to glucopyranoside, indicating that there was one glucose unit. The UV spectrum in $\mathrm{MeOH}$ showed absorption at $345 \mathrm{~nm}$, which is a characteristic absorption of orientin. ${ }^{37-39}$ Compound 3 was elucidated by a combination of ${ }^{1} \mathrm{H},{ }^{13} \mathrm{C},{ }^{13} \mathrm{C}$ DEPT, COSY, HSQC, and HMBC experiments and by comparing with assignments previously reported for isovitexin. ${ }^{40,41}$ The UV spectrum of compound 2 was an indication of hydroxyl groups at C-4', C-5, and C-7 because of the presence of a bathochromic shift with $\mathrm{NaOMe}$, $\mathrm{NaOAC}$, and $\mathrm{AlCl}_{3} / \mathrm{HCl}$ in its UV spectrum. The IR spectrum of compound 3 showed absorptions at $3440 \mathrm{~cm}^{-1}(\mathrm{OH}), 1660 \mathrm{~cm}^{-1}$ $(C=0), 1620 \mathrm{~cm}^{-1}(C=C), 1523,1475 \mathrm{~cm}^{-1}$ (aromatic group), and $1017 \mathrm{~cm}^{-1}(\mathrm{C}-\mathrm{O})$. The ${ }^{1} \mathrm{H}$ NMR spectrum of compound 3 showed six aromatic proton resonances from $\delta 6$ to 8 . A set of four AA'BB' proton signals at $\delta 7.62\left(2 \mathrm{H}, d, J=8 \mathrm{~Hz}, \mathrm{H}-2^{\prime}\right.$ and $\left.\mathrm{H}-6^{\prime}\right)$ and $6.84\left(2 \mathrm{H}, d, J=8 \mathrm{~Hz}, \mathrm{H}-3^{\prime}, \mathrm{H}-5^{\prime}\right)$ were located on ring $\mathrm{B}$, and $\mathrm{H}-8$ and $\mathrm{H}-3$ protons were observed as singlets at $\delta 6.5$ $(1 \mathrm{H})$ and $6.25(1 \mathrm{H})$, respectively. The anomeric proton showed a doublet at $4.88 \mathrm{ppm}(1 \mathrm{H}, d, J=8 \mathrm{~Hz}$, glucosyl $\mathrm{H}-1$ "). Sugar proton signals overlapped at 3.5-4.7 ppm. This ion was formed by the loss of $\mathrm{C}_{5} \mathrm{H}_{10} \mathrm{O}_{5}$ from the molecular ion. On the basis of UV, IR, NMR, and El mass data, which correlated with the literature, compound 3 was identified as isovitexin.

Extracts and concoctions from medicinal plants still play vital functions in managing primary health requirements in most developing countries. Most of the world's population (80\%) depends on these herbs and botanicals as reported by the World Health Organization, and there are active chemical constituents present in these plants responsible for the biological activity. ${ }^{42}$ It is therefore of immense concern to evaluate these plants in order to validate their employment in old-age medicine and to reveal the secondary metabolites responsible for pharmacological activity. Most of these medicinal plants reportedly contain flavonoids. Various flavonoids have been isolated from such, i.e. apigenin, galangin, kaempferol, quercetin, luteolin, naringenin, and other flavonoids, and many

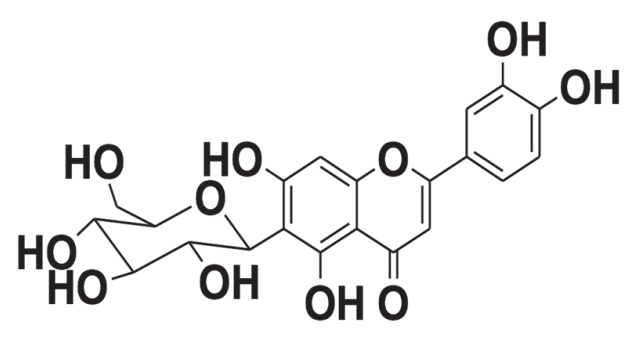

1

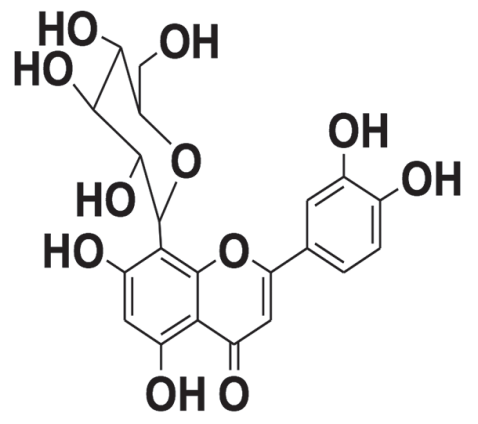

2<smiles>O=c1cc(-c2ccc(O)cc2)oc2cc(O)c(C(O)OCC(O)C3OC(O)C(O)C(O)C3O)c(O)c12</smiles>

Figure 2. Isolated flavonoids from Vitex grandifolia 
are MAO inhibitors. ${ }^{43}$ Zarmouh et al. ${ }^{44}$ reported the selective MAO-B inhibitors of isolated compounds from the ethanolic extract of Psoralea corylifolia seeds, a medicinal plants known for its antiaging effects. In that work, human recombinant MAO-B and MAO-A iso-enzymes were employed for the inhibition of enzymes studies. The authors discovered that, out of the eight compounds isolated, only two flavonoids, i.e. bavachinin and genistein, showed significant selectivity of MAO-B inhibition; these two flavonoids showed significant reduction in $\mathrm{H}_{2} \mathrm{O}_{2}$ produced by MAO-B as compared to MAO-A.44 Lee et al. ${ }^{45}$ isolated four flavonoids, namely isoquercitrin, quercitrin, quercetin, and rutin from the leaves of Melastoma candidum D. Don for the first time. These flavonoids displayed selective inhibitory activity against MAO-B with $\mathrm{IC}_{50}$ values of $19.06,11.64,3.89$, and $10.89 \mu \mathrm{M}$, respectively..$^{45}$ Monoamine oxidase inhibitors (MAOIs) differ by their selectivity of the MAO receptor. Some MAOIs inhibit both MAO-A and MAO-B equally. Other MAOls have been developed and found to target one over the other. ${ }^{46}$ Some studies here corroborate our work that some flavonoids from natural sources can selectively inhibit MAO-B.

\section{CONCLUSION}

There is growing attention on the assessment of medicinal plants especially for inhibition of MAO, owing to the likely daily and cultural use as food and vegetables. Chemical constituents in medicinal plants help in the management of disorders associated with the nervous system together with their likely connections with medicines and the diet abundant in dietary monoamines. The present study ascertained that the isolated compounds from $V$. grandifolia are moderate MAO-B inhibitors, and this result could be of importance for better application of this wild vegetable in traditional neuropharmacological use. The use of $V$. grandifolia as a vegetable is widely accepted although tagged as a "poor man's" food, and this study hopes to promote its pivotal role as a source for the development of nutraceutical products. No work or study has reported the inhibition of MAO-A and -B by constituents of this plant with anti-inflammatory activity.

Conflict of Interest: No conflict of interest was declared by the authors

\section{REFERENCES}

1. Ames BN, Shigenaga MK, Hagen TM. Oxidants, antioxidants and degenerative diseases of aging. Proc Natl Acad Sci. 1993;90:7915-7922.

2. Shih JC, Chen K, Ridd MJ. Monoamine oxidase: From genes to behaviour. Annu Rev Neurosci. 1999;22:197-217.

3. Salah N, Miller NJ, Paganga G, Tijburg L, Bolwell GP, Rice-Evans C. Polyphenolic flavanols as scavengers of aqueous phase radicals and as chain breaking antioxidants. Arch Biochem Biophy. 1995;322:339-346.

4. Liu YH, Wu WC, Lu YL, Lai YJ, Hou WC. Antioxidant and amine oxidase inhibitory activities of Hydroxyurea. Biosci Biotech Biochem. 2010:74:1256-1260.

5. Silverman RB, Ding CZ, Gates KS. Design and mechanism of monoamine oxidase inactivators from an organic chemical perspective. In: Testa B, Kyburz E, Fuhrer W, Giger R, eds. Perspectives in Medicinal Chemistry.
Basel, Weinheim, New York; Verlag Helvetica Chomica Acta; 1993;7386.

6. Kanazawa I. Short review on monoamine oxidase and its inhibitors. European Neurology. 1994;34:36-39.

7. Abell CW, Kwan SW. Molecular characterization of monoamine oxidase A and B. Prog Nucleic Acids Res Mol Biol. 2009;65:129-156.

8. Viña J, Sastre J, Pallardó F, Borrás C. Mitochondrial theory of aging: importance to explain why females live longer than males. Antioxid Red Signal. 2003;5:549-556.

9. Bratkov VM, Shkondrov AM, Zdraveva PK, Krasteva IN. Flavonoids from the genus Astragalus: Phytochemistry and biological activity. Pharmacogn Rev. 2016;10:11-32.

10. Yadav P, Malpathak N. Estimation of antioxidant activity and total phenol, flavonoid content among natural populations of caper (Capparis moonii, Wight) from Western Ghats region. Indian J Pharm Educ Res. 2016;50:495-501.

11. Oliveira FGS, Gomes de Lima-Saraiva SR, Oliveira AP, Rabêlo SV, Rolim LA, Silva Almeida JRG.Influence of the extractive method on the recovery of phenolic compounds in different parts of Hymenaea martiana Hayne. Pharmacog Res. 2016;8:270-275.

12. El-gizawy HA, Hussein MA. Isolation, structure elucidation of ferulic and coumaric acids from Fortunella japonica swingle leaves and their structure antioxidant activity relationship. Free Rad Antioxid. 2017;7:2330.

13. Venkatesan A, Kathirvel A, Prakash S, Sujatha V. Antioxidant, antibacterial activities and identification of bioactive compounds from Terminalia chebula bark extracts. Free Rad Antioxid. 2017;7:43-49.

14. Dutta S, Das S. A study of the anti-inflammatory effect of the leaves of Psidium guajava Linn. on experimental animal models. Pharmacog Res. 2010;2:313-317.

15. Middleton EJ, Kandaswami C, Theoharides TC. The effects of plant flavonoids on mammalian cells: Implications for inflammation, heart disease, and cancer. Pharmacol Rev. 2000;52:673-751.

16. Havsteen $\mathrm{BH}$. The biochemistry and medical significance of the flavonoids. Pharmacol Ther. 2002;96:67-202.

17. Fiala ES, Reddy BS, Weisburger JH. Naturally occurring anticarcinogenic substances in foodstuffs. Annu Rev Nutr. 1985;5:291-321.

18. Tapsell LC, Hemphill IL, Cobiac CS, Patch CS, Sullivan DR, Fenech M, Roodenrys S, Keogh JB, Clifton PM, Williams PG, Fazio VA, Inge KE. Health benefits of herbs and spices: The past, the present, the future. Med J Aust. 2006;185:S4-S24.

19. Triggiani V, Resta F, Guastamacchia E, Sabbà C, Licchelli B, Ghiyasaldin S, Tafaro E. Role of antioxidants, essential fatty acids, carnitine, vitamins, phytochemicals and trace elements in the treatment of diabetes mellitus and its chronic complications. Endocr Metab Immune Disord Drug Targets. 2006;6:77-93.

20. Epidi TT, Odili EO. Biocidal activity of selected plant powders against Triboleum castaneum Herbst in stored groundnut (Arachis hypogaea L.). African J Env Sci Tech. 2009;3:1-5.

21. Burkill HM. The Useful Plants of West Tropical Africa. (2nd ed). Vol. 3. Families J-L. Royal Botanic Gardens, Kew. 1995;857.

22. Samoylenko V, Rahman MM, Tekwani BL, Tripathi LM, Wang YH, Khan SI, Khan IA, Miller LS, Vaishali, CJ, Muhammad I. Banisteriopsis caapi, a unique combination of MAO inhibitory and antioxidative constituents for 
the activities relevant to neurodegenerative disorders and Parkinson's disease. J Ethnopharm. 2010;127:357-367.

23. Narayan DC, Mohamed Al, Ilias M, Larry AW, Babu LT. Monoamine oxidase inhibitory constituents of propolis: kinetics and mechanism of inhibition of recombinant human MAO-A and MAO-B. Molecules. 2014;19:18936-18952.

24. Bankova V, Popova M, Trusheva B. Propolis volatile compounds: Chemical diversity and biological activity: A review. Chem Cent J. 2014;8:28.

25. Quang DN, Harinantenaina L, Nishizawa T, Hashimoto T, Kohchi C, Soma G, Asakawa Y. Inhibition of nitric oxide production in RAW 264.7 cells by azaphilones from Xylariaceous fungi. Biol Pharm Bull. 2006;29:34-37.

26. Zhao J, Khan SI, Wang M, Vasquez $\mathrm{Y}$, Yang MH, Avula B, Wang $\mathrm{YH}$, Avonto C, Smillie TJ, Khan IA. Octulosonic acid derivatives from Roman chamomile (Chamaemelum nobile) with activities against inflammation and metabolic disorder. J Nat Prod. 2014;77:509-515.

27. Al-Taweel AM, El-Shafae AM, Perveen S, Fawzy GA, Khan SI. Antiinflammatory and cytotoxic constituents of Bauhinia retusa. Int J Pharm. 2015;11:372-376.

28. Li YL, Ding CX, Liao ZX. Glycosides from Swertia erythrosticta. Chin Trad Herb Drugs. 2002;33:104-106.

29. Song DM, Sun QS. Chemical studies on constituents of Trollius altaicus CA. Mey Medi Chem. 2004;14:233-235.

30. Ju Y, Sacalis JN, Still CC. Bioactive flavonoids from endophyte-infected blue grass (Poa ampla). J Agric Food Chem. 1998;46:3785-3788.

31. Kumazawa TT, Minatogawa S, Matsuba S. Sato S, Onodera J. An effective synthesis of isoorientin: the regioselective synthesis of a 6-C-glucosylflavone. Carbohydr Res. 2000;329:507-513.

32. Cheng G, Bai Y, Zhao Y, Tao J, Liu Y, Tu G, Ma L, Liao N, Xu X. Flavonoids from Ziziphus jujuba Mill var. spinosa. Tetrahedron. 2000;56:8915-8920.

33. Wang TY, Li Q, Bi KS. Bioactive flavonoids in medicinal plants: structure, activity and biological fate. Asian J Pharm Sci. 2018;13:12-23.

34. Çelik $H$, Koşar M. Inhibitory effects of dietary flavonoids on purified hepatic NADH-cytochrome b5 reductase: structure-activity relationships. Chem Biol Interact. 2012;197:103-109.

35. Isoda H, Motojima H, Onaga S, Samet I, Villareal MO, Han J. Analysis of the erythroid differentiation effect of 574 flavonoid apigenin on K562 human chronic leukemia cells. Chemico-biol Interact. 2014;575:269277.

36. Spencer JP, Vafeiadou K, Williams RJ, Vauzour D. Neuroinflammation: modulation by 635 flavonoids and mechanisms of action. Molecular Aspects Med. 2012;33:83-97.

37. Yang J, Kwon YS, Kim MJ. Isolation and characterization of bioactive compounds from Lepisorus thunbergianus (Kaulf.) Arabian J Chem. 2015;8:407-413.

38. Zhou X, Peng J, Fan G, Wu Y. Isolation and purification of flavonoid glycosides from Trollius ledebouri using high-speed counter-current chromatography by stepwise increasing the flow-rate of the mobile phase. J Chromatography A. 2015;1092:216-221.

39. Sharma KK, Sharma AK, Sharma MC, Tanwar K. Isolation of orientin and vitexin from stem bark of Parkinsonia aculeata (Caesalpiniaceae) and their successive blending on sheep wool fiber. Inter J Pharm Phy Res. 2014;6:557-561.

40. Hosoya T, Yun YS, Kunugi A. Five novel flavonoids from Wasabia japonica. Tetrahedron. 2005;61:7037-7044.

41. Peng J, Fan G, Hong Z, Chai Y, Wu Y. Preparative separation of isovitexin and isoorientin from Patrinia villosa Juss by high-speed counter-current chromatography. J Chromatogr A. 2005;1074:111-115.

42. Endo Y, Hayashi H, Sato T, Maruno M, Ohta T, Nozoe S. Confluentic acid and 2'-O-methylperlatolic acid, monoamine oxidase B inhibitors in a Brazilian plant, Himatanthus sucuuba. Chem Pharm Bull. 1994:42:11981201.

43. Lin RD, Hou WC, Yen KY, Lee MH. Inhibition of monoamine oxidase $B$ (MAO-B) by Chinese herbal medicines. Phytomed. 2003;10:650-656.

44. Zarmouh N, Eyunni S, Mazzio E, Messeha S, Elshami F, Soliman K. Bavachinin and genistein, two novel human monoamine oxidase-B (MAO-B) inhibitors in the Psoralea Corylifolia seeds. The FASEB J. 2015; 29:(Supple1).

45. Lee MH, Lin RD, Shen LY, Yang LL, Yen KY, Hou WC. Monoamine oxidase $B$ and free radical scavenging activities of natural flavonoids in Melastoma candidum D. Don. J Agric Food Chem. 2001;49:5551-5555.

46. Ficarra R, Ficarra P, Tommasini S, Carulli M, Melardi S, Di Bella MR, Calabrò ML, De Pasquale R, Germanò MP, Sanogo R, Casuscelli F. Isolation and characterization of Guiera senegalensis J. F. Gmel. active principles. Boll Chim Farm. 1997;136:454-459. 